\title{
Turkish Insulin Injection Technique Study: Population Characteristics of Turkish Patients with Diabetes Who Inject Insulin and Details of Their Injection Practices as Assessed by Survey Questionnaire
}

\author{
Selcuk Dagdelen · Oguzhan Deyneli · Nermin Olgun • Zeynep Osar Siva • Mehmet Sargin • \\ Sükrü Hatun · Mustafa Kulaksizoglu • Ahmet Kaya • Cansu Aslan Gürlek • Laurence J. Hirsch • \\ Kenneth W. Strauss (D) on behalf of the ITQ Turkish Study Group
}

Received: May 23, 2018 / Published online: June 30, 2018

(C) The Author(s) 2018

\section{ABSTRACT}

Introduction: Over 7 million people in Turkey have diabetes. Of the 1 million who inject insulin little is known of their habits and injection techniques.

Enhanced Digital Features To view enhanced digital features for this article go to https://doi.org/10.6084/ m9.figshare.6552746.

For centers participating in the ITQ Turkey Study Group and their location, see Table 1. For types of insulin used in Turkey, see Table 12).

\section{S. Dagdelen}

Department of Endocrinology and Metabolism, Hacettepe University School of Medicine, Hacettepe Mah., Sihhiye, 06230 Ankara, Turkey

\section{O. Deyneli}

Department of Endocrinology and Metabolism, School of Medicine, Koc University, Davutpasa Cad. No:4, Topkap1, 34010 Istanbul, Turkey

N. Olgun

Nursing Department, Faculty of Health Sciences, Hasan Kalyoncu University, Havaalanı Yolu Üzeri 8. km. Sahinbey, Gaziantep, Turkey

\section{Z. O. Siva}

Department of Endocrinology, Diabetes and Metabolism, Istanbul University Cerrahpasa School of Medicine, Cerrahpasa Mah. Kocamustafapasa Cad. No:53, Fatih, 34098 Istanbul, Turkey
Methods: We conducted an Injection Technique Questionnaire (ITQ) survey throughout Turkey that involved 1376 patients from 56 centers. Turkish values were compared with those from 41 other countries participating in the ITQ, known here as Rest of World (ROW).

Results: The majority (50.4\%) of Turkish insulin users give four injections/ day as opposed to ROW, where only $30.9 \%$ do. The abdomen is the most common injection site used by Turkish patients, but they also inject insulin in multiple body sites more often than do patients in ROW. Body mass index values in Turkey were 0.75 units higher than those in ROW as was the mean total daily dose (average daily dose [ADD]) of insulin (54.0 IU in Turkey vs. $47.4 \mathrm{IU}$

\section{Sargin}

Faculty of Medicine, Istanbul Medeniyet University, Egitim Mah. Dr. Erkin Cad, Kadıköy, 34722 Istanbul, Turkey

\section{S. Hatun}

Department of Pediatric Endocrinology and Diabetes, Koc University School of Medicine, Davutpasa Cad. No: 4, Topkap1, 34010 Istanbul, Turkey

M. Kulaksizoglu · A. Kaya Faculty of Medicine Department of Endocrinology and Metabolism, Necmettin Erbakan University Meram, Yunus Emre Mah. Beysehir Cad. No:281, Meram, 42080 Konya, Turkey 
in ROW). Mean glycated hemoglobin (HbA1c) in Turkey was $9.1 \%$, which is higher than in ROW and possibly related to the higher BMI and ADD. Turkish patients use insulin analogs (short and long-acting) more frequently than do patients in ROW. The shortest pen needles $(4 \mathrm{~mm})$ are used by about one-third of patients in Turkey, but the longer ones $(8 \mathrm{~mm})$ are equally common. Needles are reused in Turkey at a rate of 3.4 injections/single needle. However, needle reuse, whether with pens or syringes, is lower in Turkey than ROW, as is the number of times a reused needle is used. More than $75 \%$ of used sharps in Turkey go into the rubbish, with nearly $6 \%$ having no protection of the tip.

Conclusion: The continued use of 8-mm needles raises the risk of intramuscular injections in Turkish patients. Despite full reimbursement, needle reuse still remains an important issue. More focus needs to be given to dwell times under the skin, reconstitution of cloudy insulant, correct use of skin folds and safe disposal of sharps.

Funding: BD Diabetes Care.

Keywords: Infusions; Injections; Insulin; Lipodystrophy; Lipohypertrophy; Needles; Needlestick; Subcutaneous

$\begin{array}{ll}\text { Abbreviations } \\ \text { BMI } & \text { Body mass index } \\ \text { DKA } & \text { Diabetic ketoacidosis } \\ \text { DM } & \text { Diabetes mellitus } \\ \text { FIT } & \text { Forum for injection technique } \\ \text { FITTER } & \begin{array}{l}\text { Forum for injection technique and } \\ \text { therapy: expert recommendations }\end{array}\end{array}$

C. A. Gürlek

BD Diabetes Care, Ruzgarlibahce Mah. S.Sinan Eroglu Cad. No:6, Akel Is Merkezi A Blok -3. Kat 34805 Kavacik Beykoz, Istanbul, Turkey

L. J. Hirsch

BD Diabetes Care, Franklin Lakes, NJ, USA

K. W. Strauss $(\bowtie)$

BD Diabetes Care, POB 13, Erembodegem-Dorp 86, 9320 Erembodegem, Belgium

e-mail: kenneth.strauss@bd.com
GCP Good clinical practice

HbA1c Glycated hemoglobin

HCP Health care professional

ID Intradermal

IM Intramuscular

ITQ Injection Technique Questionnaire

IU International Unit (of insulin)

LH Lipohypertrophy

NPH Neutral protamine hagedorn (also known as Insulin N)

PD Pharmacodynamics

PK Pharmacokinetics

SC Subcutaneous

SD Standard deviation

T1DM Type 1 diabetes

T2DM Type 2 diabetes

TDD Total daily dose (of insulin)

\section{INTRODUCTION}

According to the 2017 International Diabetes Federation Atlas the prevalence of diabetes is increasing worldwide and that by 2045 Turkey will be among the top ten countries in the world in terms of total number of people with diabetes [1]. The most recent TURDEP II study, which evaluated the prevalence of and risk factors for diabetes in Turkish adults, found that $13.7 \%$ of the general population has diabetes [2]. This translates into more than seven million Turks having diabetes, of whom $13.6 \%$ are on insulin therapy (more than a million people in total).

The insulin Injection Technique Questionnaire (ITQ) is a survey tool that is written in simple layman's terms which assesses all important aspects of insulin injection, from the choice of injecting device to the disposal of used sharps, and from the essential techniques of injecting to the psychological and social aspects of the experience. The ITQ includes one questionnaire for patients and another for the diabetes healthcare professional caring for them. Both are administered in the healthcare setting during routine patient visits and usually took 30-45 min to complete.

A worldwide insulin ITQ study was conducted from February 2014 to June 2015. This 
Table 1 The Insulin Injection Technique Questionnaire Turkey Study Group, 2014-2015

\begin{tabular}{|c|c|c|}
\hline City & Center & Patients \\
\hline Adana & Çukurova Üniversitesi Tip Fakültesi Balcali Hastanesi & 32 \\
\hline Afyon & Afyon Kocatepe Üniversitesi Hastanesi & 31 \\
\hline Amasya & Amasya Sabuncuoğlu Şerafettin Eğitim Ve Araştirma Hastanesi & 25 \\
\hline Ankara & Ankara Atatürk Eğitim Ve Araştirma Hastanesi & 25 \\
\hline Ankara & Dr. Sami Ulus Kadin Doğum, Çocuk Sağliği Ve Hastaliklari Eğitim Ve Araştirma Hastanesi & 37 \\
\hline Ankara & Hacettepe Üniversitesi Tip Fakültesi ErişkiinHastanesi & 32 \\
\hline Ankara & Hacettepe Üniversitesi Tip Fakültesi İhsan Doğramaci Çocuk Hastanesi & 21 \\
\hline Ankara & Özel Bayindir Hastanesi & 35 \\
\hline Ankara & Dişkapi Yildirim Beyazit Eğitim Ve Araştirma Hastanesi & 25 \\
\hline Antalya & Akdeniz Üniversitesi Hastanesi & 25 \\
\hline Denizli & Denizli Devlet Hastanesi & 29 \\
\hline Antalya & Antalya Eğitim Araş tirma Hastanesi & 6 \\
\hline Balikesir & Ayvalik Devlet Hastanesi & 18 \\
\hline Balikesir & Devlet Hastanesi & 25 \\
\hline Bolu & Abant İzzet Baysal Üniversitesi Tip Fakültesi Hastanesi & 25 \\
\hline Bursa & Bursa Şevket Yilmaz Eğitim Ve Araştirmahastanesi & 19 \\
\hline Bursa & Uludağ Üniversitesi Tip Fakültesi Hastanesi & 33 \\
\hline Bursa & Bursa Yenişehir Devlet Hastanesi & 25 \\
\hline Çanakkale & Çanakkale Devlet Hastanesi & 16 \\
\hline Diyarbakir & Çocuk Hastaliklari Hastanesi & 25 \\
\hline Düzce & Atatürk Devlet Hastanesi & 31 \\
\hline Edirne & Trakya Üniversitesi Tip Fakültesi Hastanesi & 31 \\
\hline Erzurum & Atatürk Üniversitesi Yakutiye Araştirma Hastanesi & 7 \\
\hline Eskiş ehir & Acibadem Eskişehir Hastanesi & 23 \\
\hline Eskiş ehir & Eskişehir Osmangazi Üniversitesi Tip Fakültesi Hastanesi & 26 \\
\hline Giresun & Giresun Devlet Hastanesi & 5 \\
\hline İstanbul & Acibadem Hastaneleri & 11 \\
\hline İstanbul & İstanbul Kanuni Sultan Süleyman Eğitim Ve Araştirma Hastanesi & 6 \\
\hline İstanbul & Marmara Üniversitesi Eğitim Ve Araştirma Hastanesi & 25 \\
\hline İstanbul & Bağcilar Eğitim Ve Araştirma Hastanesi & 30 \\
\hline İstanbul & İstanbul Üniversitesi Cerrahpaşa Tip Fakültesi Hastanesi & 25 \\
\hline İstanbul & Haseki Eğitim Ve Araştirma Hastanesi & 30 \\
\hline İstanbul & İstanbul Üniversitesi İstanbul Tip Fakültesi Hastanesi & 24 \\
\hline
\end{tabular}


Table 1 continued

\begin{tabular}{|c|c|c|}
\hline City & Center & Patients \\
\hline İstanbul & Dr. Lütfi Kirdar Kartal Eğitim Ve Araştirma Hastanesi & 25 \\
\hline İstanbul & Pendik Kaynarca Semt Polikliniği Diyabet Merkezi & 32 \\
\hline İstanbul & Medeniyet Üniversitesi Göztepe Eğitim Ve Araştirma Hastanesi & 26 \\
\hline İstanbul & Şişli Hamidiye Etfal Eğitim Ve Araş tirma Hastanesi & 25 \\
\hline İstanbul & Ümraniye Eğitim Ve Araştirma Hastanesi & 28 \\
\hline İzmir & Dokuz Eylül Üniversitesi Tip Fakültesi Hastanesi & 26 \\
\hline İzmir & Ege Üniversitesi Tip Fakültesi Hastanesi & 31 \\
\hline Kayseri & Erciyes Üniversitesi Tip Fakültesi Hastanesi & 25 \\
\hline Kayseri & Kayseri Eğitim Ve Araştirma Hastanesi & 36 \\
\hline Kocaeli & Kocaeli Devlet Hastanesi & 25 \\
\hline Kocaeli & Kocaeli Üniversitesi Tip Fakültesi Hastanesi & 25 \\
\hline Konya & Konya Eğitim Ve Araş tirma Hastanesi & 25 \\
\hline Konya & Necmettin Erbakan Üniversite Hastanesi Meram Tip Fakültesi & 29 \\
\hline Malatya & Malatya Devlet Hastanesi Dahiliye Servisi & 7 \\
\hline Mersin & Mersin Devlet Hastanesi & 25 \\
\hline Mersin & Mersin Üniversitesi Tip Fakültesi Hastanesi & 31 \\
\hline Ordu & Ordu Devlet Hastanesi & 30 \\
\hline Samsun & Ondokuz Mayis Üniversitesi Tip Fakültesi Hastanesi & 25 \\
\hline Sivas & Cumhuriyet Üniversitesi Tip Fakültesi Hastanesi & 36 \\
\hline Sivas & Sivas Numune Hastanesi & 26 \\
\hline Tekirdağ & Tekirdağ Devlet Hastanesi & 30 \\
\hline Trabzon & Karadeniz Teknik Üniversitesi Tip Fakültesi Farabi Hastanesi & 25 \\
\hline Zonguldak & Bülent Ecevit Üniversitesi Uygulama Ve Araştirma Hastanesi & 32 \\
\hline TOTAL & & 1376 \\
\hline
\end{tabular}

survey involved 42 countries and 13,289 patients $[3,4]$. Turkey was one of the principal countries which participated, with an input of 1376 patients from 56 centers that represented all of the major regions of the country (Table 1). Of interest to Turkish healthcare providers (HCP), this insulin ITQ evaluated the techniques used by Turkish insulin users when injecting themselves. Little was known on this subject until the present study. The various language versions of the ITQ questionnaire (including Turkish) are available at www. fitter4diabetes.com. The findings of the worldwide insulin ITQ study forms the basis for the New Insulin Delivery Guidelines which were recently published worldwide $[5,6]$ and in Turkey. A Turkish national guideline based on the results of this study has recently been 
published and distributed to all hospitals and HCP involved in diabetes management, with the endorsement and support of the Turkish Ministry of Health [7].

The study reported here was undertaken to improve our understanding of the key injecting parameters of the estimated one million Turkish diabetic patients who use insulin daily. A correct injection technique is critical to achieving optimal insulin action; of equal importance is the type and dose of insulin used (with the latter usually receiving the most attention from the HCP). Unless insulin is delivered correctly, adjustments of dose and insulin type are unlikely to result in clinical improvements. Therefore, an understanding of exactly how Turkish patients inject insulin is essential to improve guidelines aimed at addressing deficiencies in the management of diabetics, to target training and to implement specific educational tools and approaches. The ITQ was administered with the aim of addressing these parameters in Turkish clinical practice and, in the long term, improving patient outcomes and lowering healthcare costs.

\section{METHODS}

The ITQ study methodology has been previously described in publications on the worldwide [3] and Indian [8] results. Similar methods for data collection and analysis were used in Turkey as in these previous studies. This study was conducted according to Good Clinical Practice rules and the Helsinki declaration. No information which could lead to the identification of a participant was made available to the sponsor, and participants were informed that their care would not be affected in any way by their participation in the study. They were not put at risk through their participation in the study nor were they paid to participate. Ethics committee approval was therefore not required, but it was obtained whenever specifically requested by a center and/or by local regulations. All 56 participating centers from 29 cities in Turkey (as in the Rest of World [ROW]) did so willingly and without financial incentive. A total of 1376 Turkish participants with diabetes for whom both patient and nurse forms were filled out were included in the ITQ database. Worldwide as well as country-specific ITQ survey data (including Turkey) are available in an interactive form on Tableau Public Adam Young's Profile website [9]. This database contains all of the raw ITQ data, both for Turkey and for ROW (by individual country), and it allows the user to select and view results for specific parameters or combinations of parameters.

\section{RESULTS}

\section{Population Descriptors}

In order to ensure we had the most representative sample of Turkish insulin injectors, we took patients 'as is', meaning if they injected insulin and had done so for $\geq 6$ months, they were included in the survey. Some of these patients had had extensive and best-in-class education and training in their injection technique of choice, while some had had no education or training at all; however, most fell somewhere in between these extremes. This variation in education and training on insulin injection is typical of Turkey and of the ROW.

Overall $82.4 \%$ of Turkish participants were adults, $51.3 \%$ were female, $33.2 \%$ had type 1 diabetes (T1DM) and $66.8 \%$ had type 2 diabetes (T2DM). These Turkish patients had had diabetes for a mean of 11.3 years and had been using insulin for an average of 6.9 years. Additional population statistics for the Turkish participants in our study, compared side to side with the ROW data, are given in Table 2 . The ROW data are the mean values of the 41 ITQ countries combined, excluding data from Turkey, which participated in the worldwide insulin ITQ study. Table 3 shows the breakdown in patient age and identity of the injector, and Table 4 shows the characteristics of Turkish participants compared to ROW data. The majority of Turkish patients used short- and long-acting insulin analogs, and the mean total daily dose (TDD), all insulins included, was 54.0 international units (IU) compared to $47.4 \mathrm{IU}$ in ROW (Table 2). As in ROW, the mean TDD of 
Table 2 Population demographics for Turkish and Rest of World patients

\begin{tabular}{|c|c|c|c|c|c|}
\hline Population demographic factors & \multicolumn{2}{|c|}{ Mean values for Turkey } & Mean ROW values ${ }^{a}$ & Turkey $(n)$ & $\operatorname{ROW}^{\mathrm{a}}(n)$ \\
\hline Age (years) & \multicolumn{2}{|l|}{45.0} & 52.7 & 1366 & 11,859 \\
\hline $\mathrm{BMI}\left(\mathrm{kg} / \mathrm{m}^{2}\right)$ & \multicolumn{2}{|l|}{28.5} & 26.3 & 1333 & 11,473 \\
\hline Mean no. of years with DM & \multicolumn{2}{|l|}{11.3} & 13.5 & 1289 & 7908 \\
\hline Age at diagnosis (years) & \multicolumn{2}{|l|}{33.6} & 40.6 & 1331 & 11,406 \\
\hline Mean no. of years on pills & \multicolumn{2}{|l|}{10.8} & 8.1 & 366 & 6241 \\
\hline Mean no. of years on insulin & \multicolumn{2}{|l|}{6.9} & 9.0 & 1235 & 7007 \\
\hline TDD regular (IU) & \multicolumn{2}{|l|}{35.9} & 26.1 & 136 & 1286 \\
\hline TDD rapid analogs (IU) & \multicolumn{2}{|l|}{36.0} & 30.9 & 681 & 2786 \\
\hline TDD NPH (IU) & \multicolumn{2}{|l|}{29.3} & 31.7 & 63 & 1071 \\
\hline TDD basal analogs (IU) & \multicolumn{2}{|l|}{25.4} & 28.1 & 917 & 3792 \\
\hline TDD premix (IU) & \multicolumn{2}{|l|}{48.7} & 41.6 & 343 & 1453 \\
\hline Overall TDD (IU) & \multicolumn{2}{|l|}{54.0} & 47.4 & 1251 & 6505 \\
\hline HbAlc (\%) & \multicolumn{2}{|l|}{9.10} & 8.35 & 1298 & 6365 \\
\hline \multicolumn{6}{|c|}{$\begin{array}{l}B M I \text { Body mass index, } D M \text { diabetis mellitus, } T T D \text { total daily dose (combined total of all insulin used in } 1 \text { day in } \\
\text { international units }(I U), N P H \text { neutral protamine hagedorn (also known as Insulin } \mathrm{N} \text { ), HbAlc glycated hemoglobin } \\
\text { a }{ }^{2} \text { ROW (Rest of World) values refer to the mean values of the } 41 \text { other ITQ participating countries combined (excluding } \\
\text { Turkey) }\end{array}$} \\
\hline \multicolumn{6}{|c|}{$\begin{array}{l}\text { Table } 3 \text { Identity of patient (or healthcare provider) who filled out the Injection Technique Questionnaire (ITQ) for the } \\
\text { Turkey insulin ITQ survey }(n=1306) \text { and for the Rest of World ITQ survey }(n=8225)\end{array}$} \\
\hline \multicolumn{2}{|l|}{ Patient/HCP identifier } & Turkey ITQ (\% & ROW ITQ (\%) & Turkey $(n)$ & ROW $(n)$ \\
\hline \multicolumn{2}{|l|}{ Self-injecting adult ( $\geq 18$ years) } & 82.4 & 91.8 & 1076 & 7551 \\
\hline \multicolumn{2}{|l|}{ Self-injecting adolescent (13-17 years) } & 10.1 & 4.1 & 132 & 337 \\
\hline \multicolumn{2}{|c|}{ Self-injecting child ( $<13$ years) } & 3.5 & 2.2 & 46 & 180 \\
\hline \multicolumn{2}{|c|}{ Parent who gives injections to his/her child } & 4.0 & 1.9 & 52 & 157 \\
\hline
\end{tabular}

HCP Healthcare provider

Turkish adolescents was nearly the same as that of adults (52.1 IU), while school-age children used an average of only $37.0 \mathrm{IU} / \mathrm{day}$, and children receiving injections from parents used only 24.7 IU/day (Table 4 ). The TDD was not significantly associated with body mass index (BMI).

\section{Devices and Key Injection Practices}

The injection devices used and needle reuse practices in Turkey versus ROW are shown in Table 5. These data clearly show that insulin pens are much more commonly used in Turkey than in ROW and that needle lengths differ significantly between Turkey and ROW. The 4-mm needle is used more commonly in Turkey $(35.1 \%)$ than ROW (21.8\%), while the $5-\mathrm{mm}$ 
Table 4 Comparison of patient characteristics in Turkish ITQ survey $(n=1376)$ and Rest of World ITQ survey $(n=11,913)$

\begin{tabular}{|c|c|c|c|c|c|c|c|c|}
\hline \multirow[t]{2}{*}{ Mean values } & \multicolumn{2}{|c|}{$\begin{array}{l}\text { Self-injecting adult (> } 18 \\
\text { years old) }\end{array}$} & \multicolumn{2}{|c|}{$\begin{array}{l}\text { Self-injecting } \\
\text { adolescent (13-17 } \\
\text { years old) }\end{array}$} & \multicolumn{2}{|c|}{$\begin{array}{l}\text { Self-injecting child } \\
\text { (<13 years old })\end{array}$} & \multicolumn{2}{|c|}{$\begin{array}{l}\text { Child receiving } \\
\text { Injections from parent }\end{array}$} \\
\hline & $\begin{array}{l}\text { Turkey } \\
(n=1076)\end{array}$ & $\begin{array}{l}\text { ROW } \\
(n=7530)\end{array}$ & $\begin{array}{l}\text { Turkey } \\
(n=132)\end{array}$ & $\begin{array}{l}\text { ROW } \\
(n=336)\end{array}$ & $\begin{array}{l}\text { Turkey } \\
(n=46)\end{array}$ & $\begin{array}{l}\text { ROW } \\
(n=180)\end{array}$ & $\begin{array}{l}\text { Turkey } \\
(n=52)\end{array}$ & $\begin{array}{l}\text { ROW } \\
(n=156)\end{array}$ \\
\hline Age (years) & 51.0 & 53.7 & 15.0 & 15.0 & 10.8 & 10.6 & 7.6 & 7.6 \\
\hline $\operatorname{BMI}\left(\mathrm{kg} / \mathrm{m}^{2}\right)$ & 30.1 & 27.9 & 21.8 & 21.9 & 18.3 & 19.0 & 17.0 & 17.4 \\
\hline HbAlc (\%) & 9.20 & 8.28 & 8.75 & 9.29 & 8.44 & 8.57 & 7.26 & 8.71 \\
\hline TDD (IU) & 56.0 & 48.1 & 52.1 & 55.4 & 37.0 & 37.8 & 24.7 & 22.3 \\
\hline $\begin{array}{r}\text { Years on } \\
\text { insulin }\end{array}$ & 7.3 & 9.3 & 5.8 & 6.1 & 4.3 & 4.3 & 3.4 & 3.7 \\
\hline \multicolumn{9}{|l|}{ Needle length } \\
\hline $4 \mathrm{~mm}(\%)$ & 28.1 & 23.3 & 51.0 & 38.1 & 70.7 & 44.3 & 76.1 & 53.7 \\
\hline $5 \mathrm{~mm}(\%)$ & 7.9 & 25.6 & 17.0 & 26.6 & 14.6 & 23.5 & 13.0 & 13.4 \\
\hline $6 \mathrm{~mm}(\%)$ & 21.1 & 21.9 & 26.0 & 20.2 & 12.2 & 19.1 & 10.9 & 14.6 \\
\hline $8 \mathrm{~mm}(\%)$ & 42.9 & 29.3 & 6.0 & 15.1 & 2.4 & 13.0 & 0.0 & 18.3 \\
\hline $\begin{array}{l}>4 \mathrm{~mm} \\
\text { combined } \\
(\%)\end{array}$ & 71.9 & 76.8 & 49.0 & 61.9 & 29.3 & 55.6 & 23.9 & 46.3 \\
\hline
\end{tabular}

needle is used by $<10 \%$ of adult Turkish patients on insulin. However, in Turkey use of the $8-\mathrm{mm}$ needle is still almost as common as that of the $4-\mathrm{mm}$ needle. The average number of times an individual pen needle is used is significantly lower in Turkey (3.42) than in ROW (4.98) (Table 5) Furthermore, among patients still reusing needles, the number of reuse times is lower among Turkish patients than among those in ROW. When asked why they reused, over $66.9 \%$ of Turkish patients who answered said that it was 'for convenience'.

\section{Injections/day and Injection Sites}

The number of injections per day in both Turkey and ROW is shown in Table 6. More than one-half of Turkish patients inject themselves or others four times per day, which is a far higher percentage than found in ROW. The percentages of Turkish patients giving themselves or others two or five injections/day are similar to those for ROW, while the percentages giving one or three injections/day are considerably lower.

The recommended injection sites are the abdomen, thigh, arm and buttocks [10-14]. Table 7 shows the sites used by Turkish patients and compares them to those used by patients in ROW, and Table 8 presents percentages for specific injecting zones or combinations of zones for both Turkey and ROW. Note that the combination of zones most commonly used are different for the bottom two rows (shown in italics), with a larger percentage of Turkish patients using a combination of abdomen/ thigh/arm sites or all four sites.

\section{Injecting Process}

Turkish patients using pens were asked how long they left the needle under the skin after the 
Table 5 Comparison of devices used and reuse practice in Turkey $(n=1366)$ and in Rest of World $(n=11,712)$

\begin{tabular}{|c|c|c|}
\hline Devices used and reuse practice & Turkey & ROW \\
\hline \multicolumn{3}{|l|}{ Device (\% used) } \\
\hline Syringe & 0.4 & 10.8 \\
\hline Pen & 97.3 & 83.9 \\
\hline Pump & 1.5 & 2.3 \\
\hline Pen and syringe & 0.8 & 3.0 \\
\hline \multicolumn{3}{|l|}{ Needle length used (mm) } \\
\hline 4 & 35.1 & 21.8 \\
\hline 5 & 9.6 & 39.6 \\
\hline 6 & 20.6 & 17.7 \\
\hline 8 & 34.7 & 20.8 \\
\hline \multicolumn{3}{|l|}{ Needle reuse $(\%)$} \\
\hline Pen & 24.2 & 59.9 \\
\hline Syringe & 6.3 & 44.5 \\
\hline \multicolumn{3}{|l|}{ Number of times pen needle reused } \\
\hline 2 & 56.8 & 28.4 \\
\hline $3-5$ & 32.3 & 40.4 \\
\hline $6-10$ & 6.8 & 16.8 \\
\hline$>10$ & 4.0 & 14.4 \\
\hline Mean times a used pen needle is used & 3.42 & 4.98 \\
\hline
\end{tabular}

plunger had been completely pushed down (dwell time; recommendations suggest $10 \mathrm{~s}$ or longer). Compliance with this guideline by Turkish patients was $48.3 \%$, which is much higher than the average compliance rate in ROW (Table 9). The size of the injection sites, skin folds and injection angles for both patients of Turkey and ROW are compared in Table 10.

Turkish patients were asked to make a mock injection while a nurse observed the technique. One of the parameters evaluated was whether the patient lifted a skin fold and, if so, whether it was lifted properly and released correctly. In Turkey, $52.3 \%$ of patients were observed to lift a skin fold and, of those who do so, $79.2 \%$ do it correctly (with one or two fingers plus the
Table 6 Comparison of the number of injections administered by patients in Turkey $(n=1352)$ and Rest of World $(n=8165)$

\begin{tabular}{lclll}
\hline $\begin{array}{l}\text { Number of } \\
\text { Injections/day }\end{array}$ & $\begin{array}{l}\text { Turkey } \\
(\%)\end{array}$ & $\begin{array}{l}\text { ROW } \\
(\%)\end{array}$ & $\begin{array}{l}\text { Turkey } \\
(n)\end{array}$ & $\begin{array}{l}\text { ROW } \\
(\boldsymbol{n})\end{array}$ \\
\hline 1 & 9.5 & 17.1 & 129 & 1394 \\
2 & 25.6 & 26.1 & 349 & 2131 \\
3 & 5.4 & 14.3 & 73 & 1167 \\
4 & 50.4 & 30.9 & 688 & 2525 \\
5 & 8.3 & 7.6 & 113 & 622 \\
6 & 0.6 & 2.3 & 8 & 189 \\
$>6$ & 0.3 & 1.7 & 4 & 137 \\
\hline
\end{tabular}

ROW refers to values from the 41 other ITQ participating countries combined (excluding Turkey)

thumb). However, less than half were observed to release the fold appropriately (option three in Table 11). We also found (data not shown) that $45.9 \%$ of Turkish patients lift a skin fold when using the 4-mm needle (where a fold is not required), while $52.2 \%$ do with the $6-\mathrm{mm}$ needle and $60.5 \%$ do so with the $8-\mathrm{mm}$ needle (both needle lengths generally require a skin fold).

\section{Insulins}

The breakdown of the major categories of insulin used in Turkey compared to ROW is shown in Table 12 . The values show that considerably more patients are using the newer analogs in Turkey, both short or long-acting, than in ROW.

Patients were queried about where they stored their insulin prior to opening it; $81.7 \%$ of Turkish patients reported storing unopened insulin in the refrigerator. After opening it, $73.3 \%$ of Turkish patients continued to store it in the fridge. Of these, only $51.6 \%$ let it stand at room temperature prior to injecting.

Turkish patients using cloudy insulin $(\mathrm{NPH}$, $\mathrm{N}$ or pre-mixed insulin) were asked if they reconstituted the insulin before injecting, and $54.2 \%$ said yes. They were then asked how many times they rolled or tipped their vial or 
Table 7 Comparison of injection sites used by Turkish insulin injectors to those used by Rest of World

\begin{tabular}{llllr}
\hline $\begin{array}{l}\text { Injection site } \\
\text { used }\end{array}$ & $\begin{array}{l}\text { Turkey } \\
(\%)^{\mathbf{a}}\end{array}$ & $\begin{array}{l}\text { ROW } \\
(\%)^{\mathbf{a}}\end{array}$ & $\begin{array}{l}\text { Turkey } \\
(\boldsymbol{n})\end{array}$ & \multicolumn{1}{l}{$\begin{array}{l}\text { ROW } \\
(\boldsymbol{n})\end{array}$} \\
\hline Abdomen & 86.5 & 91.3 & 1158 & 10,449 \\
Thigh & 80.1 & 41.9 & 1072 & 4802 \\
Buttocks & 20.5 & 13.3 & 275 & 1527 \\
Arm & 84.2 & 28.1 & 1127 & 3211 \\
$\begin{array}{l}\text { Total no. of } \\
\text { patients }\end{array}$ & & 1376 & 11,447 \\
$\begin{array}{l}\text { Total sites used by } \\
\text { these patients }\end{array}$ & & 3881 & 19,989 \\
\multicolumn{2}{l}{$\begin{array}{l}\text { a Percentages add to over } \\
\text { more than one site }\end{array}$} & & & \\
\hline
\end{tabular}

Table 8 Comparison of injection sites used (alone or in combination) by Turkish insulin injectors and those used by Rest of World

\begin{tabular}{|c|c|c|c|c|}
\hline \multirow[t]{2}{*}{ Injection sites } & \multicolumn{2}{|c|}{ Turkey } & \multicolumn{2}{|c|}{ ROW } \\
\hline & $\overline{\%^{a}}$ & $n$ & $\overline{\%^{a}}$ & $n$ \\
\hline Abdomen alone & 6.5 & 90 & 46.1 & 5275 \\
\hline Thigh alone & 1.6 & 22 & 3.1 & 350 \\
\hline Arm alone & 2.7 & 37 & 2.0 & 227 \\
\hline Abdomen/thigh & 6.7 & 92 & 17.8 & 2033 \\
\hline Abdomen/arm & 8.4 & 116 & 6.4 & 736 \\
\hline Thigh/arm & 6.6 & 91 & 2.3 & 267 \\
\hline Abdomen/thigh/arm & 44.8 & 616 & 9.0 & 1032 \\
\hline Abdomen/buttocks/arm & 1.2 & 16 & 0.9 & 101 \\
\hline Thigh/buttocks/arm & 1.9 & 26 & 0.5 & 55 \\
\hline All 4 & 16.1 & 222 & 6.8 & 774 \\
\hline
\end{tabular}

Italics emphasize the different combinations

a Percentages add to less than 100 because other combinations if sites were reported, but at percentages $<1 \%$

pen to reconstitute the insulin before injecting it (recommendations suggest 20 rolls or tips are necessary to completely remix crystalline
Table 9 Comparison of dwell times after pen injection in Turkish insulin injectors and those of Rest of World

\begin{tabular}{lll}
\hline Dwell time & $\begin{array}{l}\text { Turkey (\%) } \\
(n=1357)\end{array}$ & $\begin{array}{l}\text { ROW (\%) } \\
(\boldsymbol{n}=7316)\end{array}$ \\
\hline$<5 \mathrm{~s}$ & 11.6 & 19.9 \\
$5-10 \mathrm{~s}$ & 37.1 & 47.2 \\
$>10 \mathrm{~s}$ & 48.3 & 28.9 \\
I'm not aware of & 2.9 & 4.1 \\
$\quad$ how long & & \\
\hline
\end{tabular}

Table 10 Comparison of size of injection sites, skin folds and injection angle in Turkish insulin injectors and those of Rest of World

\begin{tabular}{lrc}
\hline $\begin{array}{l}\text { Injection sites/skin folds/injection } \\
\text { angle }\end{array}$ & Turkey & ROW \\
\hline Size of injection area (Abdomen) & & \\
$\quad$ Postcard & 11.6 & 57.9 \\
Playing card & 37.1 & 19.0 \\
Credit card & 48.3 & 15.4 \\
Postage stamp & 2.9 & 7.7 \\
Injection into a skin fold & & \\
Injection into skin at $90^{\circ}$ angle & 82.3 & 65.9 \\
\hline a $n=1214$ (Turkey); $n=8394$ (ROW) & & \\
b $n=1349$ (Turkey); $n=6904$ (ROW) & \\
c $n=1358$ (Turkey); $n=6950$ (ROW) & \\
& &
\end{tabular}

insulin). Table 13 shows that only $13.6 \%$ of Turkish patients using cloudy insulins comply with this guideline. Of these, patients, $80.8 \%$ tip or roll them only 10 times or less.

Patients were queried about whether they ever skipped injections and, if so, how often and why. In Turkey, $48.8 \%$ of patients admitted they skip injections; the frequency of skipping injections is shown in Table 14. The most common reason given was 'I forgot' (49.1\%). Patients were also asked if they disinfected the skin before injections, and $28.3 \%$ said they did. Only $2.5 \%$ of Turkish patients give their injections through clothing. 
Table 11 Timing of release of skin fold

\begin{tabular}{lll}
\hline When released? & Turkey $(\%)(n=708)$ & \% ROW $(n=4737)$ \\
\hline (1) Once the needle is in the skin & 8.5 & 20.0 \\
(2) Once the insulin is totally injected & 44.2 & 31.9 \\
(3) Once the insulin is injected and the needle is removed from the skin & 47.3 & 48.0 \\
\hline
\end{tabular}

Table 12 Type of insulins used in Turkey and Rest of World

\begin{tabular}{|c|c|c|c|c|c|c|}
\hline Type of Insulin & \multicolumn{2}{|c|}{$\begin{array}{l}\text { Percentage of injections in Turkey } \\
\text { given with this insulin }\end{array}$} & \multicolumn{2}{|c|}{$\begin{array}{l}\text { Percentage of injections in ROW } \\
\text { given with this insulin }\end{array}$} & $\begin{array}{l}\text { Turkey } \\
(n)\end{array}$ & $\begin{array}{l}\text { ROW } \\
(n)\end{array}$ \\
\hline $\begin{array}{l}\text { Short-acting human } \\
\text { R or Regular) }\end{array}$ & \multicolumn{2}{|l|}{5.2} & \multicolumn{2}{|l|}{19.8} & 111 & 2217 \\
\hline $\begin{array}{l}\text { Rapid-acting } \\
\text { analogue }\end{array}$ & \multicolumn{2}{|l|}{33.0} & \multicolumn{2}{|l|}{25.5} & 702 & 2863 \\
\hline $\mathrm{NPH}$ & \multicolumn{2}{|l|}{2.9} & \multicolumn{2}{|l|}{9.4} & \multicolumn{2}{|r|}{1055} \\
\hline Long-acting analogue & \multicolumn{2}{|l|}{43.2} & \multicolumn{2}{|l|}{32.6} & \multicolumn{2}{|l|}{917} \\
\hline $\begin{array}{l}\text { Pre-mix human or } \\
\text { analog }\end{array}$ & \multicolumn{2}{|l|}{15.7} & \multicolumn{2}{|l|}{122.7} & \multicolumn{2}{|l|}{333} \\
\hline Total injections & \multicolumn{2}{|l|}{100.0} & \multicolumn{2}{|l|}{100.0} & \multicolumn{2}{|r|}{$11,209^{\mathrm{b}}$} \\
\hline \multicolumn{7}{|c|}{$\begin{array}{l}\text { Total number of injections is }>1307 \text { (number of Turkish patients responding) since many were using more than one type } \\
\text { of insulin } \\
\text { b Total number of injections is }>6506 \text { (number of ROW patients responding) since many were using more than one type } \\
\text { of insulin }\end{array}$} \\
\hline \multirow{2}{*}{\multicolumn{3}{|c|}{$\begin{array}{l}\text { Table } 13 \text { Number of times cloudy insulin tipped or rolled } \\
\text { before Injecting }\end{array}$}} & \multicolumn{4}{|c|}{ Table 14 Frequency of skipping injections } \\
\hline & & & \multirow{4}{*}{$\begin{array}{l}\text { Frequency } \\
\text { Often (several times a } \\
\text { week) }\end{array}$} & \multirow{2}{*}{$\begin{array}{l}\text { Turkey }(\%) \\
(n=672)\end{array}$} & \multirow{2}{*}{\multicolumn{2}{|c|}{$\begin{array}{l}\text { ROW (\%) } \\
(n=4230)\end{array}$}} \\
\hline \multirow{2}{*}{$\begin{array}{ll}\text { Number of } \\
\text { rolls/tips }\end{array}$} & \multirow{2}{*}{$\begin{array}{l}\text { Turkey }(\%) \\
(n=396)^{\mathbf{a}}\end{array}$} & \multirow{2}{*}{$\begin{array}{l}\text { ROW (\%) } \\
(n=2746)^{\mathrm{a}}\end{array}$} & & & & \\
\hline & & & & 14.6 & 7.6 & \\
\hline 2 & 4.0 & 7.8 & & & & \\
\hline 3 & 4.8 & 7.7 & Sometimes (several & 37.1 & 35.7 & \\
\hline 4 & 3.8 & 5.7 & times a month) & & & \\
\hline 5 & 14.6 & 16.4 & $\begin{array}{l}\text { Almost never (several } \\
\text { times a year) }\end{array}$ & 48.4 & 56.7 & \\
\hline 8 & 4.5 & 3.2 & & & & \\
\hline
\end{tabular}

\begin{tabular}{rrr}
10 & 43.7 & 33.2 \\
15 & 5.6 & 4.2 \\
20 & 13.6 & 9.7 \\
\hline
\end{tabular}

${ }^{a}$ Percentages add up to $<100$ because other numbers of rolls/tips were reported, but at percentages of $<1 \%$

\section{Needlestick Injuries}

When asked if there was anyone in their immediate surroundings who might accidentally receive a sharps injury, $10.9 \%$ of Turkish patients said yes (Table 15). Over $16 \%$ of patients reported a sharps injury had already 
Table 15 Persons in household at risk for sharps Injury

\begin{tabular}{lll}
\hline Who? & $\begin{array}{l}\text { Turkey (\%) } \\
(\boldsymbol{n}=\mathbf{1 9 4})\end{array}$ & $\begin{array}{l}\text { ROW (\%) } \\
(\boldsymbol{n}=\mathbf{1 8 9 7})\end{array}$ \\
\hline Children & 36.1 & 33.2 \\
$\begin{array}{l}\text { Other family members } \\
\quad \text { e.g. spouse) }\end{array}$ & 52.6 & 47.4 \\
$\begin{array}{l}\text { Nurse or other } \\
\text { healthcare } \\
\text { professional }\end{array}$ & 3.6 & 5.4 \\
$\begin{array}{l}\text { House keeper or rubbish } \\
\text { collector }\end{array}$ & 7.7 & 14.0 \\
\hline
\end{tabular}

occurred to one of these persons. The conditions patients may have which might put others at risk for a blood-borne pathogen are shown in Table 16. Table 17 shows how used sharps are disposed, and Table 18 shows what happens to containers when they are full.

\section{DISCUSSION}

Until our ITQ survey little was known about where, when and how Turkish patients use insulin. Our study covered the entire country, with 1376 patients surveyed from 56 centers in 29 cities (Table 1). Our demographic data (Table 2) shows that our patient population is representative of Turkish T1DM and T2DM patients who inject insulin.

We found a HbA1c of $9.1 \%$, which is consistent with the results of the other multicenter studies conducted in Turkey $[15,16]$ and higher than the mean HbA1c of $8.35 \%$ reported for ROW (Table 2). This higher value could be attributable to higher levels of obesity among
Table 17 Disposal habits for used sharps

\begin{tabular}{lll}
\hline $\begin{array}{l}\text { Where are sharps } \\
\text { disposed? }\end{array}$ & $\begin{array}{l}\text { Turkey (\%) } \\
(\boldsymbol{n}=\mathbf{1 3 5 9})\end{array}$ & $\begin{array}{l}\text { ROW (\%) } \\
(\boldsymbol{n}=\mathbf{1 1 , 4 2 6})\end{array}$ \\
\hline $\begin{array}{l}\text { Into a container specially } \\
\text { made for used sharps }\end{array}$ & 7.9 & 22.2 \\
$\begin{array}{l}\text { Into a home container } \\
\quad \text { such as an empty bottle }\end{array}$ & 13.5 & 24.2 \\
$\begin{array}{l}\text { Into the rubbish with the } \\
\text { cap on }\end{array}$ & 70.0 & 45.5 \\
$\begin{array}{l}\text { Into the rubbish without } \\
\text { recapping }\end{array}$ & 5.8 & 7.0 \\
$\begin{array}{l}\text { I clip off the needle and it } \\
\text { stays in the clipper }\end{array}$ & 2.8 & 1.1 \\
\hline
\end{tabular}

Turkish diabetics patients as the BMI values were 0.75 units higher in Turkey than in ROW. Most of this difference in BMI value is attributable to the adult patients (BMI of 30.1 vs. 27.9 for ROW), while Turkish children and adolescents had BMI values equivalent to those in ROW (Table 4). Turkish patients use insulin analogs (short and long-acting) more frequently than patients in ROW (Tables 2, 12). The majority of Turkish insulin users give four injections/day, which is higher than the number reported in ROW. Turkish patients inject insulin in multiple body sites, which is also more often than do patients in ROW. The two most popular injection site combinations are the abdomen/thigh/arm and abdomen/thigh/ buttocks/arm (Tables 7,8 ). These combinations, both involving the use of thighs and arms, are especially relevant when considering the shallow subcutaneous depth in the limbs with reference to the needle lengths used (Table 5).

Table 16 Risk factors for sharps injury

\begin{tabular}{lll}
\hline Reason & Turkey $(\%)(\boldsymbol{n}=\mathbf{2 3 6})$ & ROW (\%) $(\boldsymbol{n}=\mathbf{2 4 4 8})$ \\
\hline I don't use devices that prevent injuries to others (safety devices) & 18.2 & 29.4 \\
I don't have appropriate disposal containers for my used sharps & 55.5 & 40.6 \\
Used sharps are sometimes left where others might get stuck & 19.1 & 25.8 \\
I'm positive for hepatitis or another blood-borne illness & 7.2 & 4.2 \\
\hline
\end{tabular}


Table 18 Ultimate disposal of sharps waste

\begin{tabular}{lll}
\hline $\begin{array}{l}\text { What do you do with the } \\
\text { waste? }\end{array}$ & $\begin{array}{l}\text { Turkey (\%) } \\
(\boldsymbol{n}=\mathbf{5 8 9})\end{array}$ & $\begin{array}{l}\text { ROW (\%) } \\
(\boldsymbol{n}=\mathbf{5 5 9 4})\end{array}$ \\
\hline Put it into the rubbish & 61.5 & 38.0 \\
Take it to a pharmacist & 0.8 & 14.1 \\
$\begin{array}{l}\text { Take it to a doctor's office } \\
\text { Take it to a laboratory }\end{array}$ & 0.5 & 6.9 \\
$\begin{array}{l}\text { Take it to the hospital or } \\
\text { clinic }\end{array}$ & 14.9 & 0.4 \\
$\begin{array}{l}\text { Take it to a local deposit } \\
\text { or collection service }\end{array}$ & 7.3 & 22.9 \\
None of the above & 14.8 & 6.3 \\
\hline
\end{tabular}

Syringe use has almost disappeared in Turkey; at the present time syringes alone are used by less than half a percent of injectors while another $0.8 \%$ use them in combination with pens (Table 5). Thus, in the remainder of this discussion we focus on insulin pen use. The shortest pen needles $(4 \mathrm{~mm})$ are used by about one-third of patients in Turkey, but the longer ones $(8 \mathrm{~mm})$ are equally common. Our 2015 ITQ revealed that there has been a great change in the size of insulin needles used in Turkey. As recently as 2008 , by far the majority $(83.5 \%)$ of Turkish patients used 8-mm needles. While it is encouraging to see the 'shift to shorts' among Turkish patients, it is still worrying to find such high percentages of patients still using the 8 -mm needle (Tables 4,5 ). In all, more than half of Turkish patients (55.3\%) are still on long pen needles.

A study of a large and heterogeneous population (four ethnic groups) of American adults with diabetes revealed that skin thickness at injection sites differed minimally by BMI (obese patients have equivalent skin thickness to thin and normal-weight ones) [17]. Strollo and Gentile recently summarized the influence of ethnic origin and skin thickness [18] and found that fat thickness (dimensions of the subcutaneous space) varies widely from individual to individual as a function of BMI, gender and injection site. Another recent study confirmed these anatomic findings in Chinese patients [19].

Hirsch at al. [20] showed that the risk of intramuscular (IM) injections with 8-mm needles is considerable in adults. This risk as a function of the length of the needle is shown in Table 19. The risk is especially high in those using the thigh and arm sites as injection sites (see values in italics in Table 19), where as many as one-fourth to one-fifth, respectively, of injections with the 8-mm needle may go into muscle. Many more Turkish patients use these sites for injections than those in ROW, with $80.1 \%$ using the thigh and $84.2 \%$ using the arm (Table 7). Our survey showed that $42.9 \%$ of adult Turkish injectors are still using the $8-\mathrm{mm}$ needle, a figure much higher than the $29.3 \%$ in ROW (Table 4). Of these, $60.5 \%$ achieve a level of safety from IM injections by using a lifted skin fold, but that still leaves nearly two out of five injectors who do not.

Table 19 Estimated intramuscular injection risk by body site

\begin{tabular}{lccccc}
\hline Needle length & Body sites combined & Thigh & Arm & Abdomen & Buttock \\
\hline $4 \mathrm{~mm}$ & $0.4 \%$ & $1.6 \%$ & $1.0 \%$ & $0.3 \%$ & $0.1 \%$ \\
$5 \mathrm{~mm}$ & $1.8 \%$ & $4.7 \%$ & $3.1 \%$ & $1.1 \%$ & $0.5 \%$ \\
$6 \mathrm{~mm}$ & $5.7 \%$ & $10.0 \%$ & $7.0 \%$ & $2.8 \%$ & $1.3 \%$ \\
$8 \mathrm{~mm}$ & $15.3 \%$ & $25.0 \%$ & $19.5 \%$ & $9.7 \%$ & $5.5 \%$ \\
$12.7 \mathrm{~mm}$ & $45.0 \%$ & $63.0 \%$ & $55.0 \%$ & $38.0 \%$ & $26.9 \%$ \\
\hline
\end{tabular}

Assumption is made that the injection is made straight in at $90^{\circ}$, without a pinch-up

Italics indicate the injection sites and needle length associated with high risk

Table is adapted from Hirsch et al. [39], with permission 
Almost $18 \%$ of our survey population was in the pediatric age range (Table 3 ). The risk of IM injections with the $8-\mathrm{mm}$ needle in children is strikingly high. Lo Presti et al. [21] reported that in children aged less than 7 years, more than four of five injections would go into the muscle when the 8-mm needle was used perpendicularly. For school-age children (7-13 years old) and for adolescents (14-18 years old), two of three injections with the 8-mm needle would go into muscle. These higher than expected percentages of Turkish children in these age groups were found by our survey to be still using needles longer than the recommended $4 \mathrm{~mm}$ : 49.0, 29.3 and $23.9 \%$ of adolescents, children and those receiving injections from their parents, respectively, used needles longer than $4 \mathrm{~mm}$ (Table 4).

Our worldwide ITQ data [3] shows that 4-mm needles are associated with lower TDD, fewer hospitalizations for hypoglycemia, lower needle reuse rates and fewer cases of lipohypertrophy (LH) (all with $p<0.05$ by multivariate analysis). In a large, randomized, prospective controlled crossover study of obese subjects taking large insulin doses, with two arms ( 4 vs. $8 \mathrm{~mm}$ and 4 vs. $12.7 \mathrm{~mm}$ ), the $4-\mathrm{mm}$ needles provided equivalent glycemic control (by HbA1c) as the $8-\mathrm{mm}$ and $12.7-\mathrm{mm}$ needles [22]. No additional skin leakage was seen with the 4-mm needles compared to the other sizes of needles. Furthermore, patients reported less pain with the $4-\mathrm{mm}$ needle.

These results are consistent with those from other comparative studies of 4-, 5- or 6-mm needles [23-30]. Miwa et al. [29] compared 4-mm needles with their 6-mm counterparts and reported equivalent safety and effectiveness results. These authors reported that their Japanese subjects found the 4-mm needle to be less painful than the 6-mm needle as well as simpler and easier to use. Nagai et al. [30] compared 4and 5-mm needles and reported similar results. Hirose et al. [31] conducted pharmacokinetic/ pharmacodynamic (PK/PD) studies and determined bioequivalent maximum concentrations and similar areas under the curve for the 4-, 6and $8-\mathrm{mm}$ needles. A crossover study using the euglycemic clamp measuring PK/PD in both normal-weight and obese, healthy adults showed similar insulin uptake and action when insulin lispro was injected with a $5-\mathrm{mm}$ needle on 1 day and an $8-\mathrm{mm}$ needle on the next day [32].

Needle reuse has been a contentious subject, with financial interests being a confounding issue on both sides of the debate. However, a Spanish study [33] showed an association between LH (which the authors found in $52 \%$ of T2DM and $72 \%$ of T1DM patients) and the reuse of needles $(p<0.05)$. There was a clear trend to greater frequency of $\mathrm{LH}$ as the number of uses (reuse) of the needle increased. The presence of LH was highest when the needle was used six times or more. Of those who reused needles, $70 \%$ had LH (84\% in T1DM) [33]. A more recent Chinese study has confirmed these findings [34].

Needle reuse, whether with pens or syringes, is lower in Turkey than in ROW, as is the number of times a reused needle is used (Table 5). When Turkish patients do reuse needles, the principal reason given is not cost as the needles have already ben fully reimbursed, but rather convenience [35].

Pen needles, syringes and lancets used in the treatment of diabetes are the most frequently used sharps in the world. Most of these are employed in the home setting, where their safe disposal after use is of critical public health importance. In Turkey, the ITQ data revealed that many persons are in the immediate surroundings of the person who is injecting/being injected, often children, who might accidentally be injured by the used sharps (Table 15). Appropriate disposal containers are not available to more than half of Turkish patients (Table 16), and conditions favorable to contamination exist even in the home setting; this includes a sero-positive rate for hepatitis and other blood-borne illnesses of $7.2 \%$ of patients, by indicated by self-reporting (Table 16). More than $75 \%$ of used sharps in Turkey go into the rubbish, with nearly $6 \%$ not even having the minimum protection of a cap (Tables 17,18 ). This represents a risk for children, home healthcare nurses, maids and household cleaners, rubbish collectors, street animals and others in the community. Furthermore, $10.9 \%$ of our survey population reported that a needlestick 
injury had already occurred sometime during their years of injecting insulin. Hence, more safety measures, including a wider use of safetyengineered devices, are clearly needed in Turkey.

\section{CONCLUSIONS}

In summary, based on our comparison of ITQ data, many of the parameters of injection practice are better in Turkey than in ROW, but we are still far from achieving our goals The continued use of $8-\mathrm{mm}$ needles by approximately one-third of Turkish patients increases the risk during IM injections. Additionally, more focus needs to be given to dwell times under the skin, reconstitution of cloudy insulins, correct use of skin folds and safe disposal of sharps. The Turkish Injection Delivery Guidelines, named the 'Insulin Injection Techniques and Treatment Guideline for Health Care Professionals', are a welcome step in this direction. These should be made available to all patients and professionals involved in insulin therapy in Turkey and should followed by all as a road map to optimal therapy. The authors plan to conduct another ITQ approximately 1 year after these guidelines are published with the aim to assess their impact on Turkish injection practice.

\section{ACKNOWLEDGEMENTS}

Our sincerest thanks go to the 1376 patient in the 56 participating centers along with their doctors and nurses and patients. (See Table 15 of the companion paper [36] for the names of all HCPs).

Funding. BD Diabetes Care sponsored this study by reimbursing hospitals for time spent. BD Diabetes Care also funded the article processing charges for this article. No healthcare professional or patient received payment for participating in the study, and no payments were given to any author for publication of this article. All authors had full access to all of the data in this study and take complete responsibility for the integrity of the data and accuracy of the data analysis.

Authorship. All named authors meet the International Committee of Medical Journal Editors (ICMJE) criteria for authorship for this manuscript, take responsibility for the integrity of the work as a whole, and have given final approval to the version to be published.

Prior Publications. This article is another in a series of country-specific analyses of the worldwide ITQ survey results. Two previous publications appeared in an issue of Diabetes Therapy in 2017 entitled "Indian Injection Technique Study: Population Characteristics and Injection Practice" [37] and "Indian Injection Technique Study: Injecting Complications, Education, and the Health Care Professional" [38], both in volume 8 .

Disclosures. Cansu Aslan is an employee of $\mathrm{BD}$, a manufacturer of injecting devices. Laurence J. Hirsch is an employee of $\mathrm{BD}$, a manufacturer of injecting devices. Kenneth W. Strauss is an employee of $\mathrm{BD}$, a manufacturer of injecting devices. All other authors (Selcuk Dagdelen, Oguzhan Deyneli, Nermin Olgun, Zeynep Osar Siva, Mehmet Sargin, Sükrü Hatun, Mustafa Kulaksizoglu and Ahmet Kaya) have nothing to disclose.

Compliance with Ethics Guidelines. All procedures performed in studies involving human participants were in accordance with the ethical standards of the institutional and/or national research committee and with the 1964 Helsinki declaration and its later amendments or comparable ethical standards. Informed consent was obtained from all individual participants included in the study. No participant identifying information was made available to the sponsor and participants were informed that their care would not be affected in any way by their participation. They were not put at risk in any way by the study and were not paid to participate. Ethics committee approval was therefore not generally required but was obtained whenever specifically requested by a 
center and/or by local regulations. All 56 participating centers from 29 cities in Turkey (as in Rest of World [ROW]) did so willingly and without financial incentive.

Data Availability. Worldwide as well as country-specific ITQ survey data (including Turkey) are available at Tableau Public Adam Young's Profile website (http://tabsoft.co/ 23V6ofi). This database contains all of the raw ITQ data, both for Turkey and ROW (by individual country), and allows the user to select and view results for specific parameters or combinations of parameters. This site allowed the generation of all datasets used in the current study.

Open Access. This article is distributed under the terms of the Creative Commons Attribution-NonCommercial 4.0 International License (http://creativecommons.org/licenses/ by-nc/4.0/), which permits any noncommercial use, distribution, and reproduction in any medium, provided you give appropriate credit to the original author(s) and the source, provide a link to the Creative Commons license, and indicate if changes were made.

\section{REFERENCES}

1. International Diabetes Federation (IDF). IDF diabetes atlas-8th edn. http://www.diabetesatlas.org/ resources/2017-atlas.html. Last accessed 12 May 2018.

2. Satman I, Omer B, Tutuncu Y, et al. Twelve-year trends in the prevalence and risk factors of diabetes and prediabetes in Turkish adults. Eur J Epidemiol. 2013;28(2):169-80. https://doi.org/10.1007/s10654013-9771-5.

3. Frid AH, Kreugel G, Grassi G. Worldwide Injection Technique Questionnaire study: population parameters and injection practices. Mayo Clin Proc 2016;91(9):1212-23. Open Access at: http://www. mayoclinicproceedings.org/article/S0025-6196(16) 30322-6/fulltext. Accessed 12 May 2018.

4. Frid AH, Kreugel G, Grassi G. Worldwide Injection Technique Questionnaire study: injecting complications and role of the professional. Mayo Clin Proc 2016;91(9):1224-30. Open Access at: http://www.
mayoclinicproceedings.org/article/S00256196(16)30326-3/fulltext. Accessed 12 May 2018.

5. Frid AH, Kreugel G, Grassi G. New insulin delivery recommendations. Mayo Clin Proc 2016;91(9): 1231-55. Open Access at: http://www.mayoclinic proceedings.org/article/S0025-6196(16)30321-4/ fulltext. Accessed 12 May 2018.

6. Drake MT, Smith SA. Optimizing insulin delivery in patients with diabetes mellitus: still room for improvement. Mayo Clin Proc 2016;91(Issue 9):155-1157. (Accompanying editorial to the three preceding Mayo Clinic Proceedings papers). Open Access at: http://www.mayoclinicproceedings.org/ article/S0025-6196(16)30410-4/fulltext. Last accessed 12 May 2018.

7. Saglık Çalısanları Için Insülin Enjeksiyon Teknikleri ve Tedavileri Kılavuzu Halk Saglıg1 Genel Müdürlügü, Yayın No: 1093, Ankara ve Yayın Tarihi: 2018.

8. Kalra S, Mithal A, Sahay R, et al. Indian Injection Technique Study: population characteristics and injection practices. Diabetes Ther. 2017;8(3): 637-57. https://doi.org/10.1007/s13300-017-0243-x.

9. yyTableau Public Adam Young's Profile website. ITQ survey data. http://tabsoft.co/23V6ofi. Last accessed 12 May 2018.

10. Bantle JP, Neal L, Frankamp LM. Effects of the anatomical region used for insulin injections on glycaemia in type 1 diabetes subjects. Diabetes Care. 1993;16:1592-7.

11. Frid A, Lindén B. Intraregional differences in the absorption of unmodified insulin from the abdominal wall. Diabet Med. 1992;9:236-9.

12. Koivisto VA, Felig P. Alterations in insulin absorption and in blood glucose control associated with varying insulin injection sites in diabetic patients. Ann Intern Med. 1980;92:59-61.

13. Annersten $M$, Willman A. Performing subcutaneous injections: a literature review. Worldviews Evid Based Nurs. 2005;2:122-30.

14. Vidal M, Colungo $\mathrm{C}$, Jansà $\mathrm{M}$. Actualización sobre técnicas y sistemas de administración de la insulina (I) [Update on insulin administration techniques and devices (I)]. Av Diabetol. 2008;24:175-90.

15. Gagliardino JJ, Atanasov PK, Chan JC, et al. Resource use associated with type 2 diabetes in Africa, the Middle East, South Asia, Eurasia and Turkey: results from the International Diabetes Management Practice Study (IDMPS). BMJ Open Diabetes Res Care. 2017;5(1):e000297. https://doi. org/10.1136/bmjdrc-2016-000297. 
16. Damci T, Emral R, Svendsen AL, Balkir T, Vora J. Lower risk of hypoglycaemia and greater odds for weight loss with initiation of insulin detemir compared with insulin glargine in Turkish patients with type 2 diabetes mellitus: local results of a multinational observational study. BMC Endocr Disord. 2014;14:61. https://doi.org/10.1186/1472-6823-14-61.

17. Gibney MA, Arce CH, Byron KJ, Hirsch LJ. Skin and subcutaneous adipose layer thickness in adults with diabetes at sites used for insulin injections: implications for needle length recommendations. Curr Med Res Opin. 2010;26:1519-30.

18. Strollo F, Gentile S. Comment on the New Indian Injection Technique Recommendations: critical appraisal of the real-world implementation of the current guidelines. Diabetes Ther. 2017;8(3): 507-11. https://doi.org/10.1007/s13300-017-0262-7.

19. Jain SM, Pandey K, Lahoti A, Rao PK. Evaluation of skin and subcutaneous tissue thickness at insulin injection sites in Indian, insulin naïve, type- 2 diabetic adult population. Indian J Endocrinol Metab. 2013;17(5):864-70.

20. Hirsch L, Byron K, Gibney M. Intramuscular risk at insulin injection sites-measurement of the distance from skin to muscle and rationale for shorter-length needles for subcutaneous insulin therapy. Diabetes Technol Ther. 2014;16(12):867-73.

21. Lo Presti D, Ingegnosi C, Strauss K. Skin and subcutaneous thickness at injecting sites in children with diabetes: ultrasound findings and recommendations for giving injection. Pediatr Diabetes. 2012;13(7):525-33.

22. Bergenstal RM, Strock ES, Peremislov D. Safety and efficacy of insulin therapy delivered via a $4 \mathrm{~mm}$ pen needle in obese patients with diabetes. Mayo Clin Proc. 2015;90(3):329-38.

23. Birkebaek N, Solvig J, Hansen B, Jorgensen C, Smedegaard J, Christiansen J. A $4 \mathrm{~mm}$ needle reduces the risk of intramuscular injections without increasing backflow to skin surface in lean diabetic children and adults. Diabetes Care. 2008;22:e65.

24. Jamal R, Ross SA, Parkes JL, Pardo S, Ginsberg BH. Role of injection technique in use of insulin pens: prospective evaluation of a 31-gauge, $8 \mathrm{~mm}$ insulin pen needle. Endocr Pract. 1999;5:245-50.

25. Kreugel G, Keers JC, Jongbloed A, Verweij-Gjaltema $\mathrm{AH}$, Wolffenbuttel BHR. The influence of needle length on glycemic control and patient preference in obese diabetic patients. Diabetes. 2009;58:A117.

26. Schwartz S, Hassman D, Shelmet J, et al. A multicenter, open-label, randomized, two-period crossover trial comparing glycemic control, satisfaction, and preference achieved with a 31 gauge $\times 6 \mathrm{~mm}$ needle versus a 29 gauge $\times 12.7 \mathrm{~mm}$ needle in obese patients with diabetes mellitus. Clin Ther. 2004;26:1663-78.

27. Kreugel G, Beijer HJM, Kerstens MN, ter Maaten JC, Sluiter WJ, Boot BS. Influence of needle size for SC insulin administration on metabolic control and patient acceptance. Eur Diab Nurs. 2007;4:1-5.

28. Van Doorn LG, Alberda A, Lytzen L. Insulin leakage and pain perception with NovoFine $6 \mathrm{~mm}$ and NovoFine $12 \mathrm{~mm}$ needle lengths in patients with type 1 or type 2 diabetes. Diabet Med. 1998;1:S50.

29. Miwa T, Itoh R, Kobayashi T, et al. Comparison of the effects of a new 32-gauge $\times 4$ - $\mathrm{mm}$ pen needle and a 32-gauge $\times 6$-mm pen needle on glycemic control, safety, and patient ratings in Japanese adults with diabetes. Diabetes Technol Ther. 2012;14(12):1084-90.

30. Nagai Y, Ohshige T, Arai K, Kobayashi H, Sada Y, Ohmori S. Comparison between shorter straight and thinner microtapered insulin injection needles. Diab Tech Ther. 2013;15(7):550-5.

31. Hirose T, Ogihara T, Tozaka S, Kanderian S, Watada H. Identification and comparison of insulin pharmacokinetics injected with a new $4-\mathrm{mm}$ needle vs 6-and 8-mm needles accounting for endogenous insulin and C-peptide secretion kinetics in non-diabetic adult males. J Diabetes Investig. 2013;4(3): 287-96.

32. de la Peña A, Yeo KP, Linnebjerg H, et al. Subcutaneous injection depth does not affect the pharmacokinetics or glucodynamics of insulin lispro in normal weight or healthy obese subjects. J Diabetes Sci Technol. 2015;9:1-7.

33. Blanco M, Hernández MT, Strauss KW, Amaya M. Prevalence and risk factors of lipohypertrophy in insulin-injecting patients with diabetes. Diabetes Metab. 2013;39(5):445-53.

34. Hirsch L, Ji L, Sun Z, Li Q, et al. Lipohypertrophyprevalence, risk factors and clinical characteristics of insulin-requiring patients in China. DTT. 2015;17[Suppl 1]:A57-8.

35. De Coninck C, Frid A, Gaspar R, et al. Results and analysis of the 2008-2009 Insulin Injection Technique Questionnaire survey. J Diabetes. 2010;2(3): 168-79.

36. Dagdelen S, Deyneli O, Olgun N, et al. Turkish insulin injection technique study: complications experienced by Turkish patients with diabetes who inject insulin, education they received and the role of health care professional as assessed by survey questionnaire. Diabetes Ther. 2018 
37. Kalra S, Mithal A, Sahay R, et al. Indian injection technique study: population characteristics and injection practices. Diabetes Ther. 2017;8(3): 637-57. https://doi.org/10.1007/s13300-017-0243-X.

38. Kalra S, Mithal A, Sahay R, et al. Indian injection technique study: injecting complications, education, and the health care professional. Diabetes
Ther. 2017;8(3):659-72. https://doi.org/10.1007/ s13300-017-0244-9.

39. Hirsch L, Byron K, Gibney M. Intramuscular risk at insulin injection sites-measurement of the distance from skin to muscle and rationale for shorter-length needles for subcutaneous insulin therapy. Diabetes Technol Ther. 2014;16(12):867-73. 